\title{
Pemberian ekstrak daun cincau (Mesona palustris BL) oral meningkatkan jumlah sel $\beta$ pankreas dan menurunkan gula darah puasa pada tikus putih (Rattus norvegicus) jantan galur Wistar diabetes
}

\author{
${ }^{1}$ Fatimah Zahra \\ ${ }^{2}$ Anak A. G. Budhiarta \\ ${ }^{3}$ Wimpie Pangkahila
}

\author{
${ }^{1}$ Program Pascasarjana Anti-Aging Medicine \\ ${ }^{2}$ Departemen Penyakit Dalam \\ ${ }^{3}$ Departemen Andrologi dan Seksologi \\ Fakultas Kedokteran Universitas Udayana Denpasar \\ Email: i_zahra@rocketmail.com
}

\begin{abstract}
Grass jelly leaf is a traditional Indonesian beverage that is believed to be beneficial for our health. This study was carried out to observe the increased number of pancreatic $\beta$ cells and the decreased fasting blood glucose in male Wistar rats with diabetes induced by streptozotocin (STZ). This was a pure experimental study with a post-test only control group design. Subjects were 36 male rats divided into 2 groups: the control group (P0), given glibenclamide dose 0.09 $\mathrm{mg} / 200 \mathrm{~g}$ rat body weight and $2 \mathrm{ml}$ aquadest as placebo; and the treatment group (P1), given glibenclamide $0.09 \mathrm{mg} / 200 \mathrm{mg}$ rat body weight and grass jelly leaf extract $54 \mathrm{mg} / 200 \mathrm{mg}$ rat body weight. Pancreatic $\beta$ cell count and blood glucose examination were performed after 28 days of treatment. The results showed that the number of pancreatic $\beta$ cells in the treatment group (P1) was statistically higher than of the control group (P0) $(56.72 \pm 5.644$ vs $29.11 \pm 2.698$ cells $(P$ $\leq 0.001)$. In addition, the fasting blood glucose level of the treatment group (P1) was statistically lower than of the control group (P0) $(79.50 \pm 37.75 \mathrm{mg} / \mathrm{dl}$ vs $191.00 \pm 123.15 \mathrm{mg} / \mathrm{dl})(P<0.001)$. Conclusion: The administration of grass jelly extract increased pancreatic $\beta$ cells and decreased fasting blood glucose level in diabetic male rats.
\end{abstract}

Keywords: grass jelly extract, fasting blood sugar, pancreatic beta cells, diabetes mellitus

\begin{abstract}
Abstrak: Daun cincau atau grass jelly (Mesona palustris BL) merupakan bahan minuman tradisional Indonesia yang dipercaya bermanfaat untuk kesehatan. Penelitian ini dilakukan untuk mengetahui adanya peningkatan jumlah sel $\beta$ pankreas dan penurunan kadar gula darah puasa pada tikus Wistar diabetes yang diinduksi streptozotocin (STZ). Jenis penelitian ialah eksperimental murni dengan post-test only control group design. Subyek penelitian ialah 36 ekor tikus putih jantan, dibagi menjadi 2 kelompok, yaitu: kelompok kontrol (P0) yang diberikan glibenklamid oral dosis $0,09 \mathrm{mg} / 200 \mathrm{gr} \mathrm{BB}$ tikus dan $2 \mathrm{ml}$ aquadest sebagai plasebo; dan kelompok perlakuan (P1) yang diberikan glibenklamid oral dosis $0,09 \mathrm{mg} / 200$ gr BB tikus dan ekstrak daun cincau dosis $54 \mathrm{mg} / 200 \mathrm{gr}$ BB tikus. Penghitungan jumlah sel $\beta$ pankreas dan pengukuran gula darah dilakukan setelah 28 hari perlakuan. Hasil penelitian menunjukkan bahwa kelompok perlakuan (P1) memiliki jumlah sel $\beta$ pankreas yang secara statistik lebih tinggi

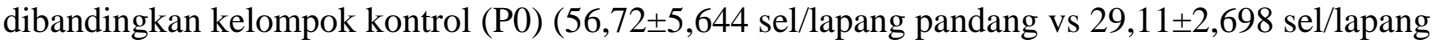
pandang) $(P \leq 0,001)$. Selain itu, kelompok perlakuan $(\mathrm{P} 1)$ memiliki kadar gula darah puasa yang secara statistik lebih rendah dibandingkan kelompok kontrol (P0) $(79,50 \pm 37,75 \mathrm{mg} / \mathrm{dl}$ vs 191,00 $\pm 123,15 \mathrm{mg} / \mathrm{dl})(P<0,001)$. Simpulan: Pemberian ekstrak daun cincau (Mesona palustris BL) meningkatkan jumlah sel $\beta$ pankreas dan menurunkan kadar gula darah puasa pada tikus (Rattus novergicus) jantan galur Wistar diabetes.
\end{abstract}

Kata kunci: ekstrak daun cincau, gula darah puasa, sel beta pankreas, diabetes melitus 
Diabetes melitus (DM) merupakan salah satu kelompok penyakit metabolik yang ditandai oleh keadaan hiperglikemia karena adanya gangguan sekresi insulin, resistensi insulin atau keduanya. Keadaan hiperglikemia kronis dari DM berhubungan dengan kerusakan jangka panjang, gangguan fungsi, dan kegagalan berbagai organ, terutama mata, ginjal, saraf, jantung, dan pembuluh darah. ${ }^{1}$ Kategori DM menurut WHO merupakan suatu penyakit global. Jumlah penderita DM di dunia diprediksikan meningkat dari 171 juta jiwa pada tahun 2000 menjadi 366 juta jiwa pada tahun $2030 .^{2}$ Menurut data statistik dari studi Global Burden of Disease WHO tahun 2004, Indonesia menempati peringkat pertama di Asia Tenggara, dengan prevalensi penyandang DM sebanyak 8.426.000 jiwa di tahun 2000 dan diperkirakan akan meningkat 2,5 kali lipat pada tahun 2030, dan merupakan penyakit penyebab kematian nomor 7 terbesar. ${ }^{3}$

Sejauh ini penggunaan insulin serta obat kimiawi sebagai jalur pengobatan DM, sering memberatkan pasien karena harga sediaan obat kimiawi tergolong mahal. Selain itu obat kimiawi dapat memberikan efek samping seperti mual, diare, hipersekresi asam lambung, vertigo, hipertiroidisme, dan lain sebagainya. Hal ini menyebabkan tingginya permintaan akan hadirnya obat anti DM baru terutama yang berasal dari herbal dan diharapkan memiliki potensial antidiabetes yang tinggi dengan efek samping yang minimal.

Indonesia merupakan salah satu negara yang kaya akan keanekaragaman hayati. Terdapat sekitar 30.000 jenis (species) yang telah diidentifikasi dan 950 species diantaranya diketahui memiliki fungsi biofarmaka, yaitu tumbuhan, hewan maupun mikroba yang memiliki potensi sebagai obat. ${ }^{4}$ Daun cincau (Mesona palustris BL) merupakan bahan pangan tradisional yang mengandung antioksidan dan yang secara empiris diyakini berkhasiat untuk menurunkan kadar gula darah pada orang yang menderita diabetes. ${ }^{5}$ Dari penelitian yang dilakukan, diketahui bahwa daun cincau memiliki aktivitas antioksidan yang tinggi dengan inhibition concentration (IC50) 46,92 ppm. ${ }^{6}$

Senyawa fenolik atau total fenol ialah komponen bioaktif daun cincau yang mempunyai sifat antioksidan, merupakan senyawa yang dicirikan memiliki satu atau lebih gugus hidroksil pada cincin aromatis. Turunan senyawa fenol banyak terjadi secara alami sebagai flavonoid, alkaloid, tannin, dan senyawa fenolat lainnya. ${ }^{7}$ Senyawa flavonoid merupakan kelompok fenol yang terbesar di alam. Flavonoid bersifat antioksidan dan telah digunakan sebagai salah satu komponen bahan baku obat-obatan. $^{8}$

Pada penelitian in vitro, didapatkan bahwa suatu senyawa fitokimia flavonoid dapat meningkatkan kemampuan sekresi insulin oleh sel $\beta$ pankreas. ${ }^{9}$ Efek anti diabetik dari senyawa fitokimia tersebut terjadi melalui berbagai mekanisme, diantaranya menurunkan absorbsi glukosa di dalam saluran cerna, menghambat pembentukan glukosa di hati, meningkatkan ambilan glukosa oleh jaringan, meningkatkan sekresi insulin oleh sel $\beta$ pankreas, dan meningkatkan regenerasi selsel $\beta$ pankreas. ${ }^{10-14}$

Berdasarkan paparan tersebut diatas, peneliti terpacu untuk meneliti efek hipoglikemik ekstrak daun cincau bila diberikan sebagai tambahan suplemen pada terapi diabetes dengan glibenklamid dan menggunakan streptozotocin (STZ) sebagai zat diabetogen.

\section{METODE PENELITIAN}

Jenis penelitian ini ialah eksperimental dengan menggunakan post-test only control group design. Subjek penelitian yang digunakan ialah tikus putih jantan (Rattus norvergicus) galur Wistar, usia 2,5-3 bulan, berat badan \pm 200 gr, yang diinduksi diabetes dengan injeksi MLD STZ hingga kadar gula darah puasa $\geq 122 \mathrm{mg} / \mathrm{dl}$. Penggunaan tikus jantan sebagai subjek disebabkan karena sifatnya lebih stabil, tidak dipengaruhi oleh siklus menstruasi dan kehamilan seperti pada tikus betina. Tikus usia 2,5 bulan memiliki persamaan dengan manusia usia dewasa muda dan 
belum mengalami proses penuaan intrinsik. Subyek penelitian 36 ekor tikus dibagi menjadi 2 kelompok masing-masing 18 ekor tikus, yaitu: kelompok I sebagai kelompok kontrol (P0) yang diberikan perlakuan dengan obat glibenklamid dosis $0,09 \mathrm{mg} / 200 \mathrm{gr}$ BB tikus dan $2 \mathrm{ml}$ aquadest sebagai plasebo; dan kelompok II ialah kelompok perlakuan (P1) yang diberikan perlakuan dengan obat glibenklamid dosis $0,09 \mathrm{mg} / 200$ gr BB tikus dan ekstrak daun cincau sebanyak $2 \mathrm{ml}$ yang setara dengan dosis $54 \mathrm{mg} / 200$ gr BB tikus. Setelah 28 hari perlakuan, dilakukan pemeriksaan kadar gula darah puasa dengan pengambilan darah vena pada canthus medial sinus orbitalis tikus. Sebelum dilakukan pengambilan darah, tikus dianestesi dahulu dengan menggunakan ketamin HCL $10 \%$ dosis $0,2 \mathrm{ml} / 200 \mathrm{gr} \mathrm{BB}$ tikus secara intramuskular. Setelah itu, tikus dieutanasia dan dinekropsi untuk pengambilan sampel organ pankreas. Organ difiksasi dengan larutan fixatif NBF $10 \%$. Preparat jaringan pankreas dibuat dengan menggunakan pewarnaan hematoksilin eosin (HE) dan diperiksa jumlah sel $\beta$ pankreas.

\section{HASIL PENELITIAN DAN BAHASAN}

Hasil penelitian menunjukkan rerata kadar gula darah puasa kelompok P0 ialah $191,00 \pm 123,15 \mathrm{mg} / \mathrm{dl}$ dan kelompok P1 ialah 79,50 $\pm 37,75 \mathrm{mg} / \mathrm{dl}(P<0,01)$ (Tabel 1). Selain itu pemeriksaan sel $\beta$ pankreas menggunakan pewarnaan HE menunjukkan rerata jumlah sel $\beta$ pankreas kelompok P0

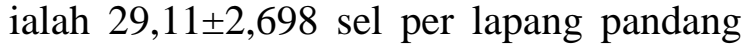
dan kelompok P1 ialah 56,72 $\pm 5,644$ sel per lapang pandang $(P<0,01)$ (Tabel 2$)$.

Tabel 1. Rerata kadar gula darah puasa antar kelompok

\begin{tabular}{lccccc}
\hline Kelompok & $\mathbf{N}$ & $\begin{array}{c}\text { Rerata gula darah puasa } \\
(\mathbf{m g} / \mathbf{d l})\end{array}$ & $\mathbf{S B}$ & $\boldsymbol{t}$ & $\boldsymbol{P}$ \\
\hline Kelompok P0 & 18 & 191,00 & 123,15 & 3,673 & 0,001 \\
Kelompok P1 & 18 & 79,50 & 37,75 & 3,673 \\
\hline \multicolumn{2}{c}{ N = jumlah sampel; SB $=$ Simpangan Baku; $\mathrm{t}=$ t-test P= signifikansi }
\end{tabular}

Tabel 2. Rerata jumlah sel $\beta$ pankreas antar kelompok

\begin{tabular}{lccccc}
\hline \multicolumn{1}{c}{ Kelompok } & $\mathbf{N}$ & $\begin{array}{c}\text { Rerata } \\
\text { (Sel/lapang pandang) }\end{array}$ & SB & $\boldsymbol{t}$ & $\mathbf{p}$ \\
\hline Kelompok P0 & 18 & 29,11 & 2,698 & $-18,72$ & 0,000 \\
Kelompok P1 & 18 & 56,72 & 5,644 & $-18,72$ \\
\hline
\end{tabular}

$\mathrm{N}=$ jumlah sampel; $\mathrm{SB}=$ Simpangan Baku; $\mathrm{t}=t$-test $; \mathrm{p}=$ signifikansi

Streptozotocin merupakan suatu nitrosourea analog yang disintesis oleh bakteri Streptomycetes archromogenes. STZ memiliki efek diabetogenik dengan menyebabkan kerusakan pada sel $\beta$ pankreas, disuntikkan secara intraperitoneal, dengan dosis $4 \mathrm{mg} / 200$ gr BB tikus/hari selama 5 hari berturut (MLD STZ). ${ }^{15}$ MLD STZ dipilih peneliti sebagai metode penyuntikan karena metode ini mampu menyebabkan hiperglikemia yang bermakna dan akan tetap bertahan dalam keadaan diabetes sampai minggu ke-5, ${ }^{16}$ dan mencegah kematian hewan coba pasca induksi STZ tunggal dosis tinggi. Oleh karena itu pada penelitian ini tidak diberikan nicotinamide yang berfungsi sebagai pelindung sel $\beta$ pankreas terhadap efek toksik STZ. ${ }^{17}$ Diharapkan dengan tanpa pemberian nicotinamide, kerusakan yang terjadi pada sel $\beta$ pankreas hewan coba serupa dengan kerusakan yang terjadi pada sel $\beta$ pankreas DM tipe 2 pada manusia.

Berdasarkan hasil penelitian di atas, didapatkan bahwa pada kelompok yang 
diberikan perlakuan obat glibenklamid dan ekstrak daun cincau terjadi penurunan kadar gula darah puasa yang lebih besar dibandingkan kelompok kontrol yang diberikan perlakuan obat glibenklamid dan plasebo saja. Hal ini disebabkan karena ekstrak daun cincau mengandung senyawa aktif seperti flavonoid sebanyak 123,7693 $\mathrm{mg} / 100 \mathrm{~g}$ QE; kadar total fenol 129,6700 $\mathrm{mg} / 100 \mathrm{~g} \mathrm{QE}$; tannin 278,0500 mg/100g QE; dan beta karoten 79,0300 mg/100g. Uji aktivitas antioksidan menunjukkan bahwa ekstrak daun cincau memiliki aktivitas antioksidan yang tinggi yaitu 447,9952 $\mathrm{mg} / \mathrm{L}$ dengan inhibition concentration $50 \%$ (IC50) sebesar 7,1758 mg/L.

Senyawa fitokimia flavonoid dapat meningkatkan kemampuan sekresi insulin dalam sel $\beta$ pankreas in vitro. ${ }^{9}$ Efek anti diabetik dari senyawa fitokimia tersebut terjadi melalui berbagai mekanisme diantaranya menurunkan absorbsi glukosa dalam saluran cerna, menghambat pembentukan glukosa di hati, meningkatkan ambilan glukosa oleh jaringan perifer, meningkatkan sekresi insulin oleh sel $\beta$ pankreas, dan meningkatkan regenerasi jaringan sel $\beta$ pankreas. ${ }^{10-14}$

Flavonoid merupakan senyawa pereduksi yang baik dan mampu menangkap radikal bebas Reactive Oxygen Species (ROS) atau Reactive Nitrogen Species (RNS). ${ }^{18}$ Efek flavonoid terhadap ROS terjadi melalui dua mekanisme yaitu meningkatkan antioksidan endogen dan menangkap radikal bebas atau menetralisir. Peningkatan antioksidan endogen oleh flavonoid telah terbukti dalam penelitian in vitro melalui peningkatan faktor transkripsi Nrf2 yang meningkatkan ekspresi protein HO1. ${ }^{19}$ Flavonoid dapat mengaktifkan ERK, JNK, dan P38 Selanjutnya mengaktifkan Nrf2 sehingga terjadi peningkatan ekspresi gen antioksidan endogen. ${ }^{20}$

Flavonoid diketahui mampu bekerja secara langsung terhadap sel $\beta$ pankreas, dengan memicu pengaktifan kaskade signal cAMP dalam memperkuat sekresi insulin yang disensitisasi oleh glukosa. ${ }^{21}$ Selain itu, kandungan flavonoid yang tinggi pada ekstrak daun cincau dapat menghambat aktivitas enzim alfa-glikosidase sehingga menunda penyerapan glukosa. ${ }^{22}$ Flavonoid juga telah diketahui sebagai antioksidan alami yang dapat melindungi sel $\beta$ pankreas dari kerusakan akibat radikal bebas. Lebih lanjut, penelitian sebelumnya melaporkan bahwa selain melindungi sel $\beta$ pankreas terhadap kerusakan akibat stres oksidatif, flavonoid juga sekaligus dapat memicu proliferasi sel $\beta$ pankreas. ${ }^{23,24}$ Senyawa flavonoid berperan dalam mengendalikan glukosa darah dengan meningkatkan sekresi insulin oleh sel $\beta$ pankreas dengan cara meningkatkan metabolisme $\mathrm{Ca}^{2+}$ dan meregenerasi sel-sel $\beta$ pankreas. Interaksinya dengan ATP-sensitif kanal $\mathrm{K}$ pada membran sel-sel $\beta$ menimbulkan depolarisasi membran dan keadaan ini akan membuka kanal Ca sehingga ion $\mathrm{Ca}^{2+}$ akan masuk ke dalam sel $\beta$ kemudian merangsang granula yang berisi insulin dan menyebabkan terjadinya sekresi insulin. ${ }^{25}$

Daun cincau juga mengandung tannin dan alkaloid yang berpotensi menurunkan kadar glukosa darah dengan cara mengurangi resistensi insulin oleh adanya protein kinase $C$-dependent up-regulation pada reseptor insulin, meningkatkan glikolisis, merangsang sekresi GLP-1 dan menghambat DPP- $4 .{ }^{26}$ Mekanisme antidiabetik suatu senyawa fitokimia dewasa ini tidak hanya diarahkan pada menurunkan glukosa darah perifer secara langsung, menurunkan absorbsi glukosa pada usus, menghambat produksi glukosa di hati, meningkatkan penggunaan glukosa oleh jaringan, dan/atau meningkatkan sekresi insulin, tetapi diarahkan pula pada efek meningkatkan regenerasi sel $\beta$ pankreas. ${ }^{27}$ Dengan demikian daun cincau (Mesona palustris $\mathrm{BL}$ ) merupakan kandidat terapi diabetes yang potensial.

\section{SIMPULAN}

Berdasarkan hasil penelitian dapat disimpulkan bahwa pemberian ekstrak daun cincau (Mesona palustris BL) oral dapat meningkatkan jumlah sel $\beta$ pankreas dan menurunkan kadar gula darah puasa tikus diabetes. 


\section{DAFTAR PUSTAKA}

1. ADA (American Diabetes Association). Standards of Medical Care in Diabetes. J Diabetes care. 2014;37 (1):S14-S80.

2. Wild S, Roclic G, Green A, Sicree R, King H. Global prevalence in diabetes: estimates for the year 2000 and projections for 2030. J Life Sci. 2004;2(5):1047-53.

3. World Health Organization. Diabetes. Fact Sheet no 312. Geneva, 2015. (serial online), [cited 2016 Jan. 28] Available from: URL: http://www.who.int/medicentre/factsh eets/fs312/en/Toni, 2005

4. Zuhud AM. Pengelolaan keanekaragaman hayati tumbuhan obat dan tumbuhan berguna. Jurnal Ethno Forest Pharmacy. 2009;4(1):1-5.

5. Widyaningsih TD, Sukardiman DA, Puwanto, Darmanto W. Efek ekstrak air cincau hitam (Mesona palustris BL) terhadap interferon gamma dan komponen imunosurveilans pada mencit Balb/C. Jurnal Bahan Alam Indonesia. 2012;8(3): 56-62.

6. Widyaningsih TD, Wijayanti N, Handayani D, Rochmawati N. Efek hipoglikemik ekstrak cincau hitam pada tikus Wistar diabetes yang diinduksi alloxan. Jurnal Kedokteran Brawijaya. 2015;28(3):202-7.

7. Vermerris $W$, Nicholson $R$. Phenolic compound biochemistry. J Biomedic. 2006;3(1):79-93.

8. Grafianita. Kadar kurkuminoid, total fenol dan aktivitas antioksidan, Simplisia Temulawak (Curcuma xanthorrhiza Roxb) pada berbagai teknik pengeringan [Skripsi]. Surakarta: Universitas Sebelas Maret; 2011.

9. Jonas J, Plant T, Gilon P, Detimary P. Multiple effect and stimulation of insulin secretion by the tyrosine kinase inhibitor genistein in normal mouse islets. J Pharmacol. 1995; 114(4):872-80.

10. Asgary S, Parkhideh S, Solhpour S. Effect of ethanilic extract of Juglans regia $\mathrm{L}$ on blood sugar in diabetesinduced rats. $\mathrm{J}$ Med Food. 2008;11(2):533-8.

11. Kamyab H, Hejrati S, Khanavi M,
Malihi F. Hepatic mechanism of the walnut antidiabetic effect in mice. Cent Eur J Biol. 2010;5(3):304-9.

12. Jelodar G, Shahram S. Effect of walnut leaf, coriander and pomegranate on blood glucose and histopatology of pancreas of alloxan induced diabetic rats. J Trad CAM. 2012;4(1):299-305.

13. Shafiee-Nick R, Parizadeh SMR, Zokaei $\mathbf{N}$, Ghorbani A. Effect of hydroalcoholic extract of Vaccinium arctostaphylos on insulin release from rat-isolated Langerhans islet. $\mathbf{J}$ Diabetic. 2011;2(1):447-52.

14. Shafiee-Nick R, Parizadeh SMR, Zokaei N, Ghorbani A. Effect of Ganoderma Lucidum hydroalcoholic extract on insulin release in rat-isolatec pancreatic islet. Avicenna J Phytomed. 2012;2(1):206-11.

15. Aulanni'am DW, Soeatmadji F, Fatchiyah, Sumitro BS. Detection of GAD 65 auto antibodies of type 1 diabetes using GAD 65-abs reagen produced from bovine brain tissue. MJI. 2005;14(1):109-205.

16. Zhang M. The characterization of high-fat diet and multiple low-dose streptozotocin induce type 2 diabetes rat model. J Diabetes Res. 2008;4(1): 52-9.

17. Szkudelski T. Streptozotocin-nicotinamide induced diabetes in rat. Characteristics of the experimental model. Experimental Biology and Medicine. (serial online), [cited 2016 Jan 23] Available from: URL: http://www.ebm.rsmjournals.com/con tent/237/5/481.237:481-490.html. 2012.

18. Lugasi A, Hovari J, Sagi KV, Biro L. The role of antioxidant phytonutriens in the prevention of diasease. J. Acta Biol. 2003;2(1):35-40.

19. Maher P, Hanneken A. Flavonoids protect retinal ganglion cells from oxidative stress-induced death. J Invest Ophthalmol Vis Sci. 2005; 46(12): 4796-803

20. Huang CS, Lii CK, Lin AH, Yeh YW, Yao HT, Li CC, et al. Protection by chrysin, apigenin, and luteolin against oxidative stress is mediated by the Nrf2-dependent up-regulation of heme oxygenase 1 and glutamate 
cysteine ligase in rat primary hepatocytes. J. Arch Toxicol. 2013; 87(2):167-78.

21. Bramahchari G. Bioflavonoids with promising anti-diabetic potentials: A critical survey: opportunity, challenge and scope of natural products. J Medicines Chemistry. 2011;2(1): 187-212.

22. Havsteen BH. The biochemistry and medical significance of the flavonoids. J Pharmacol Therapy. 2002;96(3):67-202.

23. Sarma G, Das S. Hypoglycemic action of seed kernel of Caesalpinia bonducella Fleming in normal and alloxaninduced diabetic albino rats. The Internet Journal of Pharmacology. 2008; 6(2): 131-139.

24. Pinent M, Castell A, Baiges I, Montagut G, Arola L, Ardévol A. Bioactivity of flavonoids on insulin-secreting cells. J Comprehensive Reviews in Food Science and Food Safety. 2008; 7(2):299-308.

25. Wibudi A, Kiranadi B, Manalu W, Winarto A, Suyono S. The traditional plant, Andrographis paniculata (Sambiloto) exhibits insulin-releasing actions in vitro. $\mathrm{J}$ Acta Med Indonesian. 2008;40(2): 63-8.

26. Sharma, A., Paliwal, G., Upadhyay, N., Tiwari, A. Therapeutic stimulation of GLP-1 and GIP protein with DPP-4 inhibitors for type-2 diabetes treatment. Journal of Diabetes and Metabolic Disorders. 2015; 4(1):15.

27. Hossein A, Shafiee-Nick R, Ghorbani A. Pancreatic beta cell protection/ regeneration with phytotherapy. Braz J Pharm Sci. 2015;51(1):12-8. 